\title{
Dietary vitamin D intake among university students and their habits concerning daily sunlight exposure - a cross-sectional study
}

\section{Unos vitamina D prehranom među studentima i njihove navike $s$ obzirom na izlaganje sunčevoj svjetlosti - presječno istraživanje}

\author{
Gordana Kenđel Jovanović ${ }^{1,3^{*}}$, Greta Krešić ${ }^{2}$, Sandra Pavičić Žeželj ${ }^{3}$
}

${ }^{1}$ Teaching Institute of Public Health of Primorsko-Goranska County, Health Ecological Department, Rijeka, Croatia

${ }^{2}$ University of Rijeka, Faculty of Tourism and Hospitality Management, Department of food and nutrition, Opatija, Croatia

${ }^{3}$ University of Rijeka, Faculty of Medicine, Department of Health Ecology, Rijeka, Croatia

${ }^{*}$ Corresponding author:

Dr. sc. Gordana Kenđel Jovanović,

dipl. ing. preh. teh. - nutr.

Teaching Institute of Public Health of

Primorsko-Goranska County, Health

Ecological Department

Krešimirova 52a, 51000 Rijeka, Croatia

E-mail: gordana.kendel-jovanovic@zzjzpgz.hr

http://hrcak.srce.hr/medicina
Abstract. Aim: To evaluate students' dietary vitamin D intake according to characteristics and habits concerning daily sunlight exposure. Methods: The study included 403 students of the University of Rijeka, Croatia that fulfilled questionnaire about their characteristics, habits, physical activity, supplement use, diet, and their daily sunlight exposure. For assessing diet quality, the Dietary inflammatory index (DII) was used. Results: Average dietary vitamin $D$ intake was $2.76 \mu \mathrm{g} /$ day, statistically highest among men $(p<0.01)$, medical sciences universities' students $(p<0.01)$, students with obesity $(p=0.03)$, highly physically active $(p=0.02)$ and smokers $(p=0.01)$. Major dietary vitamin $D$ sources were fish $(42 \%, p<0.01)$ and meat and meat products $(31 \%)$. Students that more frequently expose themselves to the sunlight were mostly men, overweight, moderately physically active, dietary supplements users, and had a diet with more anti-inflammatory potential, higher dietary vitamin $D$ intake and its major dietary sources. Those who rarely and never used a sunscreen had a more anti-inflammatory diet and higher vitamin $D$ and its major food sources intakes. Diet with more pro-inflammatory potential had students that rarely or never directly expose themselves to the sunlight, likewise the students that frequently used sunscreen. Those subgroups also had the lowest dietary vitamin $D$ intake. Conclusions: The average dietary vitamin $D$ intake by investigated university students satisfied only the fifth of the recommended daily vitamin $D$ intake. Students with habits that can influence the lower synthesis of vitamin $D$ may increase the risk of diseases related to bone health, immunity and inflammation in their future life. Provided results about students' habits of their exposure to the sunlight might be useful for public health messages toward sufficient sunlight exposure, diet quality with more anti-inflammatory potential, vitamin D supplements use, and vitamin D deficiency prevention.

Key words: diet; inflammation; students; sunlight; vitamin D

Sažetak. Cilj: Procijeniti unos vitamina D prehranom u studentskoj populaciji s obzirom na njihove karakteristike i navike dnevnom izlaganju sunčevom svjetlu. Metode: $\mathrm{U}$ istraživanju su sudjelovala 403 studenta Sveučilišta u Rijeci, u Hrvatskoj, koji su ispunili upitnik o svojim karakteristikama, navikama tjelesne aktivnosti, prehrani, upotrebi dodataka prehrani te o svakodnevnom izlaganju sunčevom svjetlu. Za procjenu kvalitete prehrane korišten je Prehrambeni upalni indeks (DII ${ }^{\circ}$. Rezultati: Prosječan prehrambeni unos vitamina D iznosio je $2,76 \mu \mathrm{g} /$ dan, statistički je bio veći među muškarcima $(p<0,01)$, studentima fakulteta medicinskih znanosti $(p<0,01)$, pretilim studentima $(p=0,03)$, onima koji su bili visoko tjelesno aktivni $(p=0,02)$ i pušačima $(p=0,01)$. Glavni prehrambeni izvori vitamina D bili su riba $(42 \%, p<0,01)$ te meso i mesni proizvodi $(31 \%)$. Studenti koji se učestalije dnevno izlažu suncu, bili su uglavnom muškarci, prekomjerne tjelesne mase, umjereno tjelesno aktivni, korisnici dodataka prehrani i prehrane s većim protuupalnim potencijalom, većim unosom vitamina D i njegovih glavnih prehrambenih izvora. Oni koji nikad nisu koristili proizvode za sunčanje ili su ih koristili rijetko, imali su više protuupalnu prehranu i veći unos 
vitamina D i njegovih glavnih prehrambenih izvora. Te podgrupe studenata također su i najmanje unosile vitamin D prehranom. Zaključci: Prosječan dnevni unos vitamina D prehranom među istraživanim studentima zadovoljio je tek petinu preporučenog dnevnog unosa vitamina D. Studenti s navikama koje mogu utjecati na smanjenu sintezu vitamina D, mogu povećati rizik od bolesti povezanih sa zdravljem kostiju, imunitetom i upalama u budućem životu. Dobiveni rezultati mogu biti vrijedni za javnozdravstvene poruke o odgovarajućem izlaganju sunčevoj svjetlosti, prehrani s većim protuupalnim potencijalom i korištenju dodataka prehrani, važnima za prevenciju nedostatka vitamina D.

Ključne riječi: prehrana; studenti; sunčeva svjetlost; upala; vitamin D

\section{INTRODUCTION}

Vitamin $D$ is a fat-soluble vitamin, essential for human life, due to its role for calcium and phosphorus homeostasis that is required for proper bone mineralization ${ }^{1}$. Essential is also because of its multiple functions and importance as his receptors have been found in the whole human body, because of his regulation of approximately $3 \%$ of the human genome, and effect on innate and adaptive immunity ${ }^{2-4}$. Vitamin $D$ consist of plant (ergocalciferol - vitamin D2) and animal form (cholecalciferol - vitamin D3). Dietary intake and supplements are the source of vitamin D2 and D3, while D3 form humans can endogenous synthetize by the skin upon ultraviolet-B irradiation of 7-dehydrocholesterol ${ }^{5}$. Vitamins D2 and D3 are hydroxylated in the liver to 25-hydroxyvitamin $D$, the major circulating form of vitamin D. Upon its hydroxylation at position 1 in the kidney, vitamin $D$ gets its fully active form, 1,25-dihydroxyvitamin $D^{5}$. The measurement of 25-hydroxyvitamin D $(25(\mathrm{OH}) \mathrm{D})$ is presently acknowledged as the best index of vitamin D status and deficiency.

Recently it has been argued about the variable definitions of vitamin $\mathrm{D}$ deficiency based on different thresholds of serum $25(\mathrm{OH}) \mathrm{D}^{6,7}$, emphasizing the needs for standardized assays that can be universally adopted to assess vitamin D status in human subjects.

According to the present definition of serum vitamin D status ${ }^{8}$, low serum vitamin D can have multiple causes, such as limited exposure to sunlight, usage of sunscreen, air pollution, problems with its absorption, and insufficient intake of foods rich in this vitamin ${ }^{9}$. The association of low serum vitamin $D$ has been found with rickets in children and osteomalacia in adults, with depression, preterm birth, asthma, schizophrenia, autoimmune disorders, obesity, diabetes mellitus, insulin resistance, cardiovascular diseases, and metabolic syndrome ${ }^{10-13}$. Recent epidemiological studies pointed that almost a billion people in the world are affected with vitamin D deficiency ${ }^{14}$, and in apparently healthy Croatians it is determined to

Average dietary vitamin $D$ intake satisfied only the fifth of recommended intake, higher intake had men, those who mostly always, often and sometimes in a day exposed themselves to the sunlight, and those who rarely used sunscreen product.

be $58 \%$ in children of age $5-6$ years ${ }^{15}$, and $63 \%$ in postmenopausal women ${ }^{16}$. There is a lack of information on vitamin D status from other population groups, to fully estimate the prevalence of vitamin D deficiency in Croatia. Besides, there is also a need to examine the causes of vitamin $D$ deficiency and precise dietary vitamin D intake, its supplement intake and habits toward sunlight exposure.

The present research aimed to evaluate the dietary vitamin D intake according to characteristics of students of the University of Rijeka in Croatia, and their habits concerning daily sunlight exposure.

\section{PARTICIPANTS AND METHODS}

\section{Participants}

This cross-sectional study, initially included 742 medical (from Faculty of Medicine) and nonmedical sciences (from Faculty of Engineering and Faculty of Tourism and Hospitality Management) students of the final years form the University of Rijeka, Croatia, but 339 were excluded due to incomplete questionnaire fulfilling. Therefore, 403 university students (235 medical sciences students, 268 non-medical students), whose questionnaire was fully completed, accounted in this research. After the brief introduction of re- 
search aims and details about questionnaire fulfilling by educated nutritionists, students anonymously and voluntary fulfilled the questionnaire. The research was conducted form February till April 2019.

\section{The questionnaire}

The questionnaire consisted of two parts. The first part had questions on students' characteristics (age, sex, body weight, height that were used for calculation of BMI $\left.\left(\mathrm{kg} / \mathrm{m}^{2}\right)\right)$, physical activity, dietary supplement use, diet, and habits of daily sunlight exposure. The second part had questions about their knowledge, attitudes and perceptions about vitamin $D$, which were used from structured questionnaire ${ }^{17}$ but modified according to the research aims by investigators. In this paper, the questions from the first part of the questionnaire is discussed.

\section{Dietary quality and Dietary inflammatory index (DII)}

For assessing the dietary intake of students, the 97-item food frequency questionnaire was used, including all food groups, with various types of major dietary vitamin D sources. Students noted the intakes of consumed food items offered in 3 serving's quantities for last week (last seven day) in frequencies presented as one to three times per week, four to six times per week, once per day, and few times per day where they noted how many times per day. For assessing diet quality, the Dietary inflammatory index (DII ) was used, as a novel and scientifically increasingly used diet quality index. DII ${ }^{\circ}$ assess the inflammatory potential of the diet ${ }^{18}$ by firstly calculating zscores from dietary data of each student as linking them to the global means and standard deviations of the food and nutrients intakes from 11 nations ${ }^{18}$. Z-scores then were converted to a percentile and centred to minimize the "right skew" by doubling the value and subtracting 1 . Each food parameter provided percentile score then was multiplied by respective inflammatory effect score to provide the food parameter-specific DII ${ }^{\bullet}$ score $^{18}$. In this research, the overall DII score of each student was calculated as a sum of thirty-seven food parameter-specific DII ${ }^{\circledR}$ scores, out of possible forty-five parameters ${ }^{18}$. They included nine pro-inflammatory (energy, protein, total fat, saturated fatty acids, trans fat, carbohydrates, cholesterol, iron and vitamin B12) and twenty-eight anti-inflammatory dietary variables (monounsaturated fatty acids, polyunsaturated fatty acids, n-3 fatty acids, n-6 fatty acids, fibre, alcohol, vitamins $A, D, E, C$ and B6, $\beta$-carotene, thiamine, riboflavin, niacin, folic acid, magnesium, selenium, zinc, flavan-3-ol, flavones, flavonols, flavonones, anthocyanidins, caffeine, garlic, onion and pepper). If provided DII ${ }^{\circledR}$ score had a positive value, larger than 0 , it was considered as a pro-inflammatory diet, while negative values, lower than 0 , as an anti-inflammatory $\operatorname{diet}^{18}$. For assessing vitamin $\mathrm{D}$ recommended intake, the national guidelines for vitamin $D$ intake

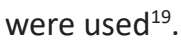

\section{Statistics}

Categorical data are presented in absolute (N) and relative frequencies (\%), and quantitative data in means and standard deviations. After testing with the Kolmogorov-Smirnov test, data were tested for differences according to gender and specific groups based on students' characteristics using t-test and Friedman ANOVA test for parametric variables with a post-hoc Scheffe test, and Chi-square test for categorical variables. For all data analyses, Statistica for Windows, version 13 (Dell Inc., Tulsa, OK, USA) was used, and a $p$-value of $<0.05$ was considered significant.

\section{RESULTS}

Statistically more women $(72.2 \%, p<0.01)$ than men $(27.8 \%)$ participated in the research, and more students from universities that teach medical sciences (Table 1). Men had statistically higher BMI values $(p<0.01)$, and were statistically more overweight and obese than women $(p<0.01)$. They also were statistically more smokers $(p<0.01)$ and were more dietary supplements users $(p<0.01)$ than women. Still, men were statistically more frequently physically active per week than women $(p<0.01)$, even though that all students were almost equally distributed across physical activity groups. Third of all students used various dietary supplement, men statistically 
Table 1. Characteristics of the university students

\begin{tabular}{|c|c|c|c|c|c|c|}
\hline Parameters & Men $^{a}$ & Women $^{a}$ & Total $^{\mathrm{a}}$ & $p$-value ${ }^{a}$ & $\begin{array}{c}\text { Dietary } \\
\text { vitamin D } \\
(\mu \mathrm{g} / \text { day })^{\mathrm{b}}\end{array}$ & $p$-value ${ }^{b}$ \\
\hline Participants & $112(27.8 \%)$ & 291 (72.2\%) & $403(100.0 \%)$ & $<0.01$ & & \\
\hline \multicolumn{7}{|l|}{ University type } \\
\hline Medical sciences & $73(65.2 \%)$ & $162(55.7 \%)$ & $235(58.3)$ & \multirow{2}{*}{0.08} & $3.33 \pm 2.42$ & \multirow{2}{*}{$<0.01$} \\
\hline Non-medical sciences & 39 (34.8\%) & $129(44.3 \%)$ & $168(41.7)$ & & $1.89 \pm 1.41$ & \\
\hline Body mass index $\left(\mathrm{kg} / \mathrm{m}^{2}\right)^{\mathrm{b}}$ & $25.38 \pm 2.94$ & $22.02 \pm 2.91$ & $22.75 \pm 2.14$ & $<0.01$ & & \\
\hline Underweight & $0(0.0 \%)$ & $16(5.5 \%)$ & $16(4.0 \%)$ & \multirow{4}{*}{$<0.01$} & $2.14 \pm 1.42$ & \multirow{4}{*}{0.03} \\
\hline Normal weight & $58(51.8 \%)$ & $245(84.2 \%)$ & $303(75.2 \%)$ & & $2.55 \pm 2.12$ & \\
\hline Overweight & 49 (43.8\%) & $23(7.9 \%)$ & $72(17.9 \%)$ & & $2.72 \pm 1.72$ & \\
\hline Obese & $5(4.4 \%)$ & $7(2.4 \%)$ & $12(2.9 \%)$ & & $4.27 \pm 4.06$ & \\
\hline \multicolumn{7}{|l|}{ Physical activity } \\
\hline$\leq 1$ per week & $4(3.6 \%)$ & 125 (43.0\%) & $129(32.0 \%)$ & \multirow{3}{*}{$<0.01$} & $2.63 \pm 1.84$ & \multirow{3}{*}{0.02} \\
\hline 2-3 per week & 49 (43.7\%) & $102(35.0 \%)$ & $151(37.5 \%)$ & & $2.43 \pm 1.74$ & \\
\hline$>3$ per week & $59(52.7 \%)$ & $64(22.0 \%)$ & $123(30.5 \%)$ & & $3.40 \pm 3.05$ & \\
\hline \multicolumn{7}{|l|}{ Smoking } \\
\hline Yes & $65(58.0 \%)$ & $89(30.6 \%)$ & $154(38.2 \%)$ & \multirow{2}{*}{$<0.01$} & $3.14 \pm 2.27$ & \multirow{2}{*}{0.01} \\
\hline No & $47(42.0 \%)$ & 202 (69.4\%) & 249 (61.8\%) & & $2.58 \pm 2.16$ & \\
\hline \multicolumn{7}{|l|}{ Dietary supplements use } \\
\hline Yes & 79 (70.5\%) & $110(37.8 \%)$ & $131(32.5 \%)$ & \multirow{2}{*}{$<0.01$} & $2.60 \pm 2.38$ & \multirow{2}{*}{0.61} \\
\hline No & $33(29.5 \%)$ & $181(62.2 \%)$ & $272(67.5 \%)$ & & $2.81 \pm 2.11$ & \\
\hline \multicolumn{7}{|l|}{ Vitamin D supplement use } \\
\hline Yes & $7(6.3 \%)$ & $12(4.1 \%)$ & 19 (4.7\%) & \multirow{2}{*}{0.37} & $3.42 \pm 2.05$ & \multirow{2}{*}{0.10} \\
\hline No & 105 (93.8\%) & 279 (95.9\%) & 384 (95.3\%) & & $2.72 \pm 2.21$ & \\
\hline
\end{tabular}

${ }^{a}$ the values are presented as number and percentage, and evaluated with Chi-square test

${ }^{b}$ the vales are presented as mean and standard deviation, and evaluated with t-test and ANOVA test with Scheffe post hoc test between groups

more than women $(70.5 \%, 37.8 \%$, respectively, $p<0.01$ ). Some kind of vitamin D supplement consumed statistically only $4.7 \%$ of all students $(p<0.01)$, with no gender difference (men $6.3 \%$; women $4.1 \%, p=0.36$ ).

\section{Diet quality and dietary vitamin D intake}

In table 2 are presented results of students' diet quality according to gender. Men had statistically higher intakes of dietary energy $(p<0.01)$, dietary fibres $(p=0.01)$, alcohol $(p=0.04)$, dietary vitamin $\mathrm{D}(p<0.01)$, and all major food groups that are dietary sources of vitamin $D$, i.e. fish $(p<0.01)$, eggs $(p<0.01)$, milk and dairy products $(p<0.01)$, and meat and meat products $(p<0.01)$. Although students' average diet had pro-inflammatory potential with DII values above 0 , men had diet with more anti-inflammatory potential than women, with statistically lower values of $\mathrm{DII}^{\circ}(p>0.01)$. In fact, $43.5 \%$ of all students had DII scores lower than zero, i.e. diet with anti-inflammatory potential, where statistical majority were women ( $71.4 \%$ of women vs $28.6 \%$ of men, $p<0.01$ ) (data not shown). According to the national guidelines for recommended daily vitamin $D$ intake ${ }^{19}$, students with average daily dietary vitamin $D$ intake of $2.76 \mu \mathrm{g}$ fulfilled only $18.38 \%$ of recommended $15 \mu \mathrm{g}$, men statistically more than women ( $28.86 \%$ vs $15.24 \% ; p<0.01$, respectively) (Table 2). When the nutrient density of vitamin $D$ in total energy intake was calculated, there was no difference between men and women $(0.39 \mu \mathrm{g} / \mathrm{MJ}$ vs $0.31 \mu \mathrm{g} / \mathrm{MJ} ; p=0.10$, respectively). Regarding students' characteristics and dietary vitamin $D$ intake (Table 1), the statistically highest intake had students from medical sciences universities $(p<0.01)$, students with obesity $(p=0.03)$, highly physically active $(p=0.02)$ and smokers $(p=0.01)$. 
Table 2. Average dietary energy and nutrient intake, and dietary inflammatory potential of the university students diet

\begin{tabular}{|c|c|c|c|c|}
\hline Parameters & Men $^{a}$ & Women $^{\mathrm{a}}$ & Total $^{\mathrm{a}}$ & $p$-value \\
\hline Dietary energy (MJ/day) & $11.56 \pm 6.90$ & $7.76 \pm 4.20$ & $8.63 \pm 5.14$ & $<0.01$ \\
\hline Proteins (\% MJ) & $16.54 \pm 2.26$ & $15.92 \pm 2.95$ & $16.07 \pm 2.81$ & 0.05 \\
\hline Lipids (\% MJ) & $42.02 \pm 6.38$ & $42.11 \pm 5.61$ & $42.09 \pm 5.75$ & 0.89 \\
\hline Carbohydrates (\% MJ) & $36.08 \pm 7.70$ & $37.79 \pm 7.63$ & $37.43 \pm 7.63$ & 0.05 \\
\hline Dietary fibres (g/day) & $22.21 \pm 12.87$ & $18.94 \pm 11.13$ & $19.78 \pm 11.62$ & 0.01 \\
\hline Alcohol (\%MJ) & $5.36 \pm 5.01$ & $4.17 \pm 5.24$ & $4.41 \pm 5.19$ & 0.04 \\
\hline Dietary inflammatory index (DII) & $0.24 \pm 3.22$ & $1.55 \pm 2.94$ & $1.24 \pm 3.04$ & $<0.01$ \\
\hline Dietary vitamin D ( $\mu \mathrm{g} /$ day) & $4.33 \pm 2.99$ & $2.29 \pm 1.67$ & $2.76 \pm 2.20$ & $<0.01$ \\
\hline $\begin{array}{l}\text { Dietary vitamin D } \\
\text { (\% of recommended intake) }\end{array}$ & $28.86 \pm 19.96$ & $15.24 \pm 11.14$ & $18.38 \pm 14.70$ & $<0.01$ \\
\hline Fish (g/day) & $53.31 \pm 50.49$ & $23.46 \pm 29.80$ & $30.26 \pm 37.30$ & $<0.01$ \\
\hline Eggs (g/day) & $55.80 \pm 47.81$ & $26.75 \pm 31.91$ & $33.38 \pm 37.79$ & $<0.01$ \\
\hline Milk and dairy products (g/day) & $535.31 \pm 581.18$ & $389.64 \pm 290.44$ & $422.43 \pm 375.17$ & $<0.01$ \\
\hline Meat and products (g/day) & $253.52 \pm 164.43$ & $151.15 \pm 104.40$ & $174.93 \pm 127.41$ & $<0.01$ \\
\hline
\end{tabular}

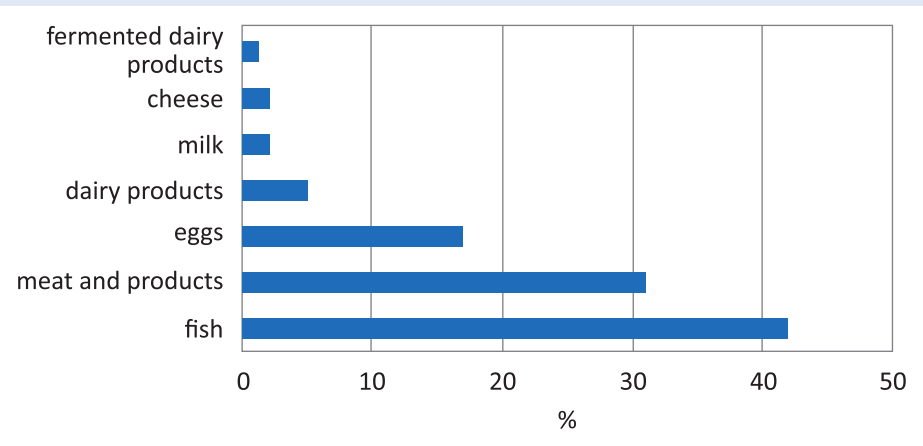

Figure 1. Major dietary sources of vitamin D in the University of Rijeka students' diet sunlight." students statistically significantly more chosen "Often" (36.7\%) and "Sometimes" (39.5\%) $(p<0.01)$, men statistically more than women $(p<0.01)$. "Always" (7.4\%) was more chosen than "Never" (0.7\%). Those students with higher values of BMI statistically more chosen "Never", and those with lower chosen "Often" $(p<0.01)$. Actually, those who were underweight and with obesity chosen "Never" more than other BMI classes, although obese students more than others chosen "Always". Those students who were low physically active statistically more chosen "Sometimes" ( $p<0.01)$, and those moderately physically active chosen "Often". Smokers and non-smokers statistically mostly chosen "Sometimes" ( $p=0.04)$. Dietary supplements users statistically more chosen "Often" (45.8\%, $p=0.03)$ than non-users who more frequently chosen "Sometimes" (42.3\%). Students who more chosen "Always" had statistically significantly the lowest DII ${ }^{\circ}$ value, i.e. diet with anti-inflammatory potential (DII=-1,85, $p<0.01)$. Diet with the most pro-inflammatory potential had students who mostly chosen "RareIy" (DII=1.76) and "Never" (DII=1.19). Statistically significant the highest dietary vitamin $D$ intake and highest values of recommended vitamin $D$ intake had students that more chosen "Always" and "Often" ( $p<0.01)$, and the lowest those who chosen "Rarely" and "Never". That was also the 
Table 3. University students' habits concerning daily sunlight exposure

\begin{tabular}{|c|c|c|c|c|c|c|}
\hline Parameters & Always & Often & Sometimes & Rarely & Never & $p$-value \\
\hline \multicolumn{7}{|c|}{ Q: During the day I am directly exposed to sunlight and regularly engage in outdoor activities for sufficient exposure to the sunlight. } \\
\hline Men $(n=112)$ & $8(7.1)$ & $50(44.6)$ & $48(42.9)$ & $5(4.5)$ & $1(0.9)$ & \multirow{3}{*}{$<0.01^{\mathrm{a}}$} \\
\hline Women $(n=291)$ & $22(7.6)$ & $98(33.7)$ & $111(38.1)$ & 58 (19.9) & $2(0.7)$ & \\
\hline Total $(n=403)$ & $30(7.4)$ & $148(36.7)$ & $159(39.5)$ & $63(15.6)$ & $3(0.7)$ & \\
\hline Body mass index $\left(\mathrm{kg} / \mathrm{m}^{2}\right)$ & $23.48 \pm 4.69$ & $22.50 \pm 2.64$ & $22.84 \pm 3.65$ & $22.69 \pm 2.58$ & $24.45 \pm 2.66$ & $<0.01^{b}$ \\
\hline Underweight $(n=16)$ & $2(12.5)$ & $5(31.3)$ & $6(37.5)$ & $2(12.5)$ & $1(6.3)$ & \multirow{4}{*}{$<0.01^{a}$} \\
\hline Normal weight $(n=303)$ & $38(12.5)$ & $127(41.9)$ & $107(35.3)$ & $31(10.2)$ & $0(0.0)$ & \\
\hline Overweight $(n=72)$ & $12(16.7)$ & $33(45.8)$ & $19(26.4)$ & $8(11.1)$ & $0(0.0)$ & \\
\hline Obese $(n=12)$ & $3(25.0)$ & $2(16.7)$ & $6(50.0)$ & $0(0.0)$ & $1(8.3)$ & \\
\hline \multicolumn{7}{|l|}{ Physical activity } \\
\hline$\leq 1$ per week $(n=129)$ & $14(10.8)$ & $28(21.7)$ & $53(41.1)$ & $34(26.4)$ & $0(0.0)$ & \multirow{3}{*}{$<0.01^{a}$} \\
\hline 2-3 per week $(n=151)$ & $3(2.0)$ & $65(43.0)$ & $64(42.4)$ & $17(11.3)$ & $2(1.3)$ & \\
\hline$>3$ per week $(n=123)$ & $17(13.8)$ & $54(43.9)$ & $40(32.5)$ & $11(9.0)$ & $1(0.8)$ & \\
\hline \multicolumn{7}{|l|}{ Smoking } \\
\hline Yes $(n=154)$ & $16(10.4)$ & $50(32.5)$ & $58(37.7)$ & 30 (19.5) & $0(0.0)$ & \multirow{2}{*}{$0.04^{a}$} \\
\hline No $(n=249)$ & $14(5.6)$ & $98(39.4)$ & $101(40.6)$ & $33(13.2)$ & $3(1.2)$ & \\
\hline \multicolumn{7}{|l|}{ Dietary supplements use } \\
\hline Yes $(n=131)$ & $8(6.1)$ & $60(45.8)$ & $44(33.6)$ & $19(14.5)$ & $0(0.0)$ & \multirow{2}{*}{$0.03^{\mathrm{a}}$} \\
\hline No $(n=272)$ & $22(8.1)$ & $88(32.4)$ & $115(42.3)$ & $44(16.1)$ & $3(1.1)$ & \\
\hline Dietary inflammatory index (DII') & $-0.99 \pm 2.24$ & $0.66 \pm 3.14$ & $1.65 \pm 3.03$ & $2.60 \pm 2.42$ & $2.05 \pm 1.98$ & $<0.01^{b}$ \\
\hline Dietary vitamin D ( $\mu \mathrm{g} /$ day) & $4.80 \pm 3.24$ & $3.02 \pm 2.47$ & $2.46 \pm 1.71$ & $1.97 \pm 1.39$ & $1.38 \pm 1.62$ & $<0.01^{b}$ \\
\hline Fish (g/day) & $59.62 \pm 42.09$ & $36.77 \pm 44.48$ & $24.10 \pm 28.62$ & $16.88 \pm 26.83$ & $22.86 \pm 27.94$ & $<0.01^{\mathrm{b}}$ \\
\hline Eggs (g/day) & $62.99 \pm 55.13$ & $37.04 \pm 37.80$ & $29.06 \pm 36.22$ & $21.74 \pm 24.32$ & $28.57 \pm 35.41$ & $<0.01^{b}$ \\
\hline Milk and dairy products (g/day) & $557.66 \pm 324.76$ & $392.17 \pm 254.88$ & $430.37 \pm 456.65$ & $410.06 \pm 316.82$ & $392.86 \pm 258.76$ & $0.04^{b}$ \\
\hline Meat and products (g/day) & $165.62 \pm 158.29$ & $181.73 \pm 131.28$ & $169.38 \pm 124.99$ & $130.15 \pm 89.09$ & $161.43 \pm 122.92$ & $0.17^{b}$ \\
\hline \multicolumn{7}{|c|}{ Q: I use sunscreen product when sunbathing. } \\
\hline Men $(n=112)$ & $14(12.5)$ & $23(20.5)$ & $39(34.8)$ & $28(25.0)$ & $8(7.2)$ & \multirow{3}{*}{$0.04^{a}$} \\
\hline Women $(n=291)$ & $66(22.7)$ & $59(20.3)$ & $106(36.4)$ & $41(14.1)$ & $19(6.5)$ & \\
\hline Total $(n=403)$ & 80 (19.9) & $82(20.3)$ & $145(36.0)$ & $69(17.1)$ & $27(6.7)$ & \\
\hline Body mass index $\left(\mathrm{kg} / \mathrm{m}^{2}\right)$ & $21.82 \pm 1.78$ & $22.66 \pm 3.44$ & $23.01 \pm 3.47$ & $22.58 \pm 2.68$ & $24.45 \pm 4.95$ & $0.04^{b}$ \\
\hline Underweight $(n=16)$ & $1(6.3)$ & $6(37.4)$ & $8(50.0)$ & $1(6.3)$ & $0(0.0)$ & \multirow{4}{*}{$0.15^{\mathrm{a}}$} \\
\hline Normal weight $(n=303)$ & $54(17.8)$ & $70(23.1)$ & $111(36.6)$ & 47 (15.5) & $21(6.9)$ & \\
\hline Overweight $(n=72)$ & $8(11.1)$ & $14(19.4)$ & $28(38.9)$ & $11(15.3)$ & $11(15.3)$ & \\
\hline Obese $(n=12)$ & $1(8.3)$ & $3(25.0)$ & $3(25.0)$ & $2(16.7)$ & $3(25.0)$ & \\
\hline \multicolumn{7}{|l|}{ Physical activity } \\
\hline$\leq 1$ per week $(n=129)$ & $29(22.5)$ & $10(15.5)$ & $50(38.8)$ & $19(14.7)$ & $11(8.5)$ & \multirow{3}{*}{$0.24^{\mathrm{a}}$} \\
\hline 2-3 per week $(n=151)$ & $22(14.6)$ & $35(23.2)$ & $55(36.4)$ & $28(18.5)$ & $11(7.3)$ & \\
\hline$>3$ per week $(n=123)$ & $23(18.7)$ & $26(21.1)$ & $37(47.3)$ & $29(23.6)$ & $8(6.5)$ & \\
\hline \multicolumn{7}{|l|}{ Smoking } \\
\hline Yes $(n=154)$ & $33(21.4)$ & $22(14.3)$ & $55(35.7)$ & $33(21.4)$ & $11(7.1)$ & \multirow{2}{*}{$0.28^{\mathrm{a}}$} \\
\hline No $(n=249)$ & $42(16.9)$ & $55(24.1)$ & $93(37.3)$ & $43(17.3)$ & $16(6.4)$ & \\
\hline \multicolumn{7}{|l|}{ Dietary supplements use } \\
\hline Yes $(n=131)$ & $30(22.9)$ & $30(22.9)$ & $38(29.0)$ & 25 (19.1) & $8(6.1)$ & \multirow{2}{*}{$0.36^{\mathrm{a}}$} \\
\hline No $(n=272)$ & 53 (19.5) & $52(19.1)$ & $104(38.2)$ & $44(16.2)$ & $19(7.0)$ & \\
\hline Dietary inflammatory index (DII') & $1.37 \pm 3.01$ & $1.74 \pm 2.93$ & $1.59 \pm 2.99$ & $-0.03 \pm 3.19$ & $1.15 \pm 2.88$ & $<0.01$ \\
\hline Dietary vitamin D ( $\mu \mathrm{g} /$ day) & $2.93 \pm 2.50$ & $2.44 \pm 1.71$ & $2.28 \pm 1.86$ & $3.85 \pm 2.49$ & $2.50 \pm 2.54$ & $0.36^{b}$ \\
\hline Fish (g/day) & $30.00 \pm 48.56$ & $26.72 \pm 30.09$ & $25.65 \pm 30.99$ & $47.75 \pm 40.25$ & $20.66 \pm 37.57$ & $0.02^{b}$ \\
\hline Eggs (g/day) & $42.61 \pm 40.20$ & $25.86 \pm 36.39$ & $24.66 \pm 27.54$ & $47.71 \pm 47.86$ & $32.14 \pm 39.45$ & $0.04^{b}$ \\
\hline Milk and dairy products (g/day) & $412.27 \pm 358.44$ & $507.49 \pm 600.74$ & $383.83 \pm 269.80$ & $416.69 \pm 263.25$ & $363.57 \pm 279.81$ & $0.03^{b}$ \\
\hline Meat and products (g/day) & $192.46 \pm 115.25$ & $152.83 \pm 118.61$ & $143.48 \pm 110.74$ & $230.87 \pm 124.02$ & $178.69 \pm 186.31$ & $0.05^{b}$ \\
\hline
\end{tabular}


same for the intake of fish $(p<0.01)$, eggs $(p<0.01)$, and milk and dairy products $(p=0.01)$. The intake of meat and meat products didn't differ across offered choices ( $p=0.17$ ).

In the question "I use sunscreen product when sunbathing.", statistically more students have chosen "Sometimes" ( $p=0.04)$, where men more chosen "Rarely" and "Never" and women more chosen "Always". Students with statistically the highest BMI ( $p=0.04)$ mostly chosen "Rarely", and those with the lowest BMI mostly chosen

Average daily diet of university students had proinflammatory potential, while men, those who always, often and sometimes in a day exposed themselves to the sunlight and those who always and often used sunscreen product had diet with more anti-inflammatory potential.

"Always". Regarding BMI classes, all classes chose "Sometimes", except students with obesity that equally chosen "Often", "Sometimes" and "Never". All physical activity groups, smoking and dietary supplements use classes mostly chosen "Sometimes", with no statistical significant difference ( $p=0.24, p=0.28$ and $p=0.36$, respectively). Students that mostly chosen "Rarely" had a diet with anti-inflammatory potential with statistically the lowest $\mathrm{DII}{ }^{\bullet}$ value $(p<0.01)$, while other groups had a diet with pro-inflammatory potential. Group that "Rarely" used sunscreen had the highest vitamin D intake ( $p=0.03$ ). They also had statistically significantly the highest intakes of its best dietary sources, fish ( $p=0.02)$, eggs $(p=0.04)$ and meat and products $(p=0.05)$. Milk and dairy products were statistically significantly most consumed by the group that "Often" used sunscreen $(p=0.03)$.

\section{DISCUSSION}

The present research revealed that investigated university students had average dietary vitamin D intake much less than recommended daily intake of $15 \mu \mathrm{g}^{19}$, satisfying only the fifth of it. Male students had dietary vitamin D intake significantly almost twice more than female students, but with no difference in its nutrient density per total energy intake, which means that dietary vitamin $D$ intake doesn't differ according to sex regarding the noticed differences in total energy intake. Representative average dietary vitamin D intakes by adults in the European countries are mostly about 3-7.5 $\mu \mathrm{g} /$ day, depending on the country ${ }^{8}$, where northern European countries had the highest intake level and southern the lowest ${ }^{8}$. The vitamin D intake by our student population was lower than mentioned average intakes, but similar to the southern and eastern European countries $^{8}$. There is a gap in the literature regarding vitamin $D$ intake by university student population, and to the available, dietary vitamin D intake by our male students was almost the same as Spanish ${ }^{20,21}$ and lower than Swedish ${ }^{22}$ male university students. Vitamin D intake by our female students was the same as Spanish female university students ${ }^{21}$. Fish and eggs are the significant dietary source of vitamin D3, while in other food of animal origin the concentration of vitamin D3 is less than $1 \mu \mathrm{g} / 100 \mathrm{~g}^{23}$. The greatest dietary source of vitamin $D$ among our students was fish, meat and eggs, where they were consumed much more by male students. On average, they consumed average portion of fish two to three times per week, and one egg per day. Milk and dairy products they consumed almost two portions per day, while meat and meat products all students consumed much more than recommended portions per day ${ }^{24}$. Mentioned dietary habits of student population have changed over the years. In the present research, the student population ate larger quantities of milk and dairy products, and of meat and meat products, lower quantities of fish, and almost the same of eggs in comparison to the student population dietary habits from the same research area ${ }^{25,26}$, although compared results are provided with different survey' dietary method than mentioned studies. Meat in average diet can provide 0.5-1.4 $\mu \mathrm{g} / 100 \mathrm{~g}$ of vitamin D323 differing on its fat quantity. Meat in average students' diet provided on average substantial $31 \%$ of their mean daily dietary vitamin D intake. Therefore, meat, along with fish intake is a great source of dietary vitamin D among investigated student population. Still, there is a difference among mention food 
items regarding other nutrients, like fatty acids content. It was shown that saturated fatty acids from meats were linked to a higher risk of cardiovascular diseases, whereas those from dairy products were linked to the lower risk ${ }^{27}$. On the other hand, a higher intake of fish, as a good source of long chain n-3 polyunsaturated fatty acid, was related to significantly lower risk of cardiovascular diseases ${ }^{28}$. It is noteworthy to mentione that $n-3$ polyunsaturated fatty acid has an important role in managing the inflammatory status of the human body. With competition for cyclooxygenase and lipoxygenase enzymes, their high dietary intake enables partial replacement of arachidonic acid, whose derivative eicosanoids (prostaglandins E2) generally are promoting inflammation $^{29}$. Vitamin D can have an anti-inflammatory effect via his involvement in inhibition of the synthesis and biological actions of pro-inflammatory prostaglandins E2 by three mechanisms: reducing prostaglandin receptors, decreasing cyclooxygenase-2 expression, and increasing 15-hydroxyprostaglandin dehydrogenase expression, which is cyclooxygenase- 2 antagonist ${ }^{30}$. Regarding the inflammatory potential of the diet due to nutrient content, it was found that average students' diet had pro-inflammatory potential, as assessed with DII', by women more than by men. This is a second Croatian research that involved diet quality assessment with DII ${ }^{\oplus 1}$, where women also had a diet with more pro-inflammatory potential men, likewise younger adults which is similar to results from present research. Diet with more pro-inflammatory potential had students that rarely or never directly expose themselves to the sunlight and regularly engage in outdoor activities for sufficient exposure to the sunlight and students that frequently used a sunscreen. Mentioned students' habits could influence their vitamin D synthesis ${ }^{8}$, which with more pro-inflammatory diet can influence immunity and the risk of diseases related to inflammation, such as cardiovascular disease ${ }^{32}$ if those habits continue to an older age. DII is a useful dietary tool which has been connected to many diseases that had its origin in the inflammatory process ${ }^{32}$, but it was mostly investigated among adults. Regarding only a few studies among student or young adult population that assessed diet with DII ${ }^{\circ}$, our students had diet with more anti-inflammatory potential than Brazilian $^{33}$ and Turkish young adults ${ }^{34}$, and similar to Spain $^{35}$ young adults. There is a need for more studies of the inflammatory potential of the diet among young adults because the majority of studies of that issue are done among older adults and various populations with particular diseases. A recent study among university students from the same universities as in this research ${ }^{36}$ revealed that third of all students were dietary supplements users, which is similar to our student sample. Among supplement users of investigated students, there were $14.5 \%$ of vitamin D supplement users, ( $4.7 \%$ of all students) which is significantly lower compared to UK adult population ${ }^{37}$ and similar to the Chinese ${ }^{38}$ student population. Previously mentioned Croatian study ${ }^{36}$ revealed that medical science students had significantly less positive attitudes about health benefits of dietary supplements than non-medical science students. It should be significant to more implicate in their better education and understanding of dietary supplement of vitamin D health benefits, as future health professionals.

As the aim of this research was to investigate students' habits for better understanding of issues connected to the vitamin D deficiency, such as daily sunlight exposure importance for vitamin $D$ synthesis. By the action of sunlight UVB radiation at 280 to $315 \mathrm{~nm}$ of length human can cutaneous synthesize vitamin $\mathrm{D}^{39}$, which can be provide $80-$ $100 \%$ of the vitamin $D$ requirements of the body ${ }^{40}$. The present research revealed that our students most often and sometimes directly expose themselves to the sunlight in a day, men more than women, which is similar to $\mathrm{UK}^{37}$, and higher than Chinese ${ }^{41}$ and Vietnam adult population $^{42}$. Though, our students more stated that are rarely exposing than always to the sunlight during the day, which is opposite to the UK adults ${ }^{37}$. Mention differences can be explained by the variances in geographical sunlight quantity and cultural behaviours by compared populations. Investigated students that more frequently in a day expose themselves to the sunlight were mostly men, overweight, moderately physically 
active, dietary supplements users, had a diet with more anti-inflammatory potential, higher dietary vitamin $D$ intake and higher intakes of major dietary vitamin $D$ sources than students who rarely or never expose themselves to the sunlight. Mentioned represent significant issues that can be used for public health promotion of daily sunlight exposure toward sufficient vitamin D synthesis among young Croatians. It was shown that application of sunscreen product on the skin can significantly decrease production of vitamin $D^{43}$. The fifth of investigated students always use sunscreen product when sunbathing, women more frequently than men, which is similar to other comparable studies ${ }^{44-46}$, but lower than Turkish $^{44}$ and Saudi Arabia ${ }^{47}$ adults. Those who always and often used sunscreen product were mostly women, normal weight, and moderately physically active. Smoking and use of dietary supplements wasn't connected to the use of sunscreen habits. Those who rarely and never used sunscreen products had a diet with more anti-inflammatory potential and higher vitamin $D$ and its major food sources intakes, which is because the majority of those students were men who had higher dietary vitamin $D$ intake and its major food sources and a diet with more anti-inflammatory potential.

The present research has its limitations and strengths. The limitation is the accuracy of dietary vitamin D intake due to possibilities of differences in the vitamin $D$ content in foods that are consumed in Croatia as we used Danish food composition tables ${ }^{23}$, for which is also difficult to compare to vitamin $\mathrm{D}$ intakes by other comparable studies. According to the dietary survey method used, we noticed that most comparable studies used a 3-day food record. In this research, it was used a 7-day food record which makes this method for assessing dietary intake more convenient for the average dietary intakes. When assessing habits concerning sunlight exposure, we used only two question from KAP-38 ${ }^{17}$, so we didn't include the duration and time of the day when exposing to the sunlight, sunscreen factor, application use of sunscreen product, which might significantly encounter to estimation of synthesis of vitamin D. Still, the strengths are that this is a first Croatian study about dietary vitamin $D$ and its sources intakes with habits concerning sunlight exposure. There is a scarce literature on the diet quality of Croatian university students that have the information about vitamin D intake, but there is also little available information on its intake by young adults worldwide, which makes it difficult for intakes comparison. However, the research strength is that it envisaged dietary intake of vitamin D by student population, their diet quality according to the inflammatory potential of the diet, which may contribute to scientific literature. Provided information from this research would be useful for future investigations about vitamin D, on knowledge, attitudes, practices and dietary intakes, especially in Croatia. As mentioned, provided information from this research might be useful for public health messages toward sufficient sunlight exposure, diet quality, vitamin D supplements use, or for prevention of vitamin $\mathrm{D}$ deficiency.

With this research results, it can be concluded that Croatian university students had insufficient dietary vitamin $D$ intake regarding recommended dietary intake, where its major dietary sources were fish and meat. Since there is a difference among those food groups consumption concerning nutrient content with inflammatory potential, fish consumption should be emphasized as a good source of vitamin D. Students' with those habits that can influence the lower synthesis of vitamin D may increase the risk of diseases related to bone health, immunity and inflammation in their future life, so this is important for future public health messages for young population. As a sunlight exposure is essential for vitamin D synthesis, students should be encouraged for sufficient daily exposure, educated about its limits, and also on sunscreen products use.

Conflicts of interest: Authors declare no conflicts of interest.

\section{REFERENCES}

1. Zadka K, Pałkowska-Goździk E, Rosołowska-Huszcz D. The State of Knowledge about Nutrition Sources of Vitamin D, Its Role in the Human Body, and Necessity of Supplementation among Parents in Central Poland. Int J Environ Res Public Health 2018;15:1489.

2. Bouillon R. Extra-Skeletal Effects of Vitamin D. Front Horm Res 2018;50:72-88. 
3. Bouillon R, Carmeliet G. Vitamin D insufficiency: Definition, diagnosis and management. Best Pract Res Clin Endocrinol Metab 2018;32:669-684.

4. Hewison M. Vitamin $D$ and the immune system: new perspectives on an old theme. Rheum Dis Clin North Am 2012;38:125-139.

5. Pludowski P, Holick MF, Grant WB, Konstantynowicz J, Mascarenhas MR, Haq A, et al. Vitamin D supplementation guidelines. J Steroid Biochem Mol Biol 2018;175: 125-135.

6. Giustina A, Adler RA, Binkley N, Bouillon R, Ebeling PR, Lazaretti-Castro $\mathrm{M}$ et al. Controversies in Vitamin $\mathrm{D}$ : Summary Statement From an International Conference. J Clin Endocrinol Metab 2019;104:234-240.

7. Cashman KD. Vitamin D Deficiency: Defining, Prevalence, Causes, and Strategies of Addressing. Calcif Tissue Int 2020;106:14-29.

8. Lips $\mathrm{P}$, Cashman KD, Lamberg-Allardt C, Bischoff-Ferrari HA, Obermayer-Pietsch B, Bianchi ML et al. Current vitamin $D$ status in European and Middle East countries and strategies to prevent vitamin $D$ deficiency: a position statement of the European Calcified Tissue Society. Eur J Endocrinol 2019;180:23-54.

9. Grineva EN, Karonova T, Micheeva E, Belyaeva O, Nikitina IL. Vitamin $D$ deficiency is a risk factor for obesity and diabetes type 2 in women at late reproductive age. $\mathrm{Ag}$ ing (Albany NY) 2013;5:575-581.

10. Zhou SS, Tao YH, Huang K, Zhu BB, Tao FB. Vitamin D and risk of preterm birth: up-to-date meta-analysis of randomized controlled trials and observational studies. J Obstet Gynaecol Res 2017;43:247-56.

11. Nassar N, Halligan GH, Roberts CL, Morris JM, Ashton AW. Systematic review of first-trimester vitamin $D$ normative levels and outcomes of pregnancy. Am J Obstet Gynecol 2011;205:1-7.

12. Kocovska E, Gaughran F, Krivoy A, Meier UC. Vitamin-D deficiency as a potential environmental risk factor in multiple sclerosis, schizophrenia, and autism. Front Psychiatry 2017;8:47-57.

13. Park JE, Pichiah PBT, Cha YS. Vitamin D and Metabolic Diseases: Growing Roles of Vitamin D. J Obes Metab Syndr 2018;27:223-232.

14. Holick MF, Binkley NC, Bischoff-Ferrari HA, Gordon CM, Hanley DA, Heaney RP et al. Evaluation, treatment, and prevention of vitamin $D$ deficiency: an Endocrine Society clinical practice guideline J Clin Endocrinol Metab 2011; 96:1911-1930.

15. Karin Z, Gilic B, Supe Domic D, Sarac Z, Ercegovic K, Zenic $\mathrm{N}$, et al. Vitamin D Status and Analysis of Specific Correlates in Preschool Children: A Cross-Sectional Study in Southern Croatia. Int J Environ Res Public Health 2018; 15:2503.

16. Laktasic-Zerjavic N, Korsic M, Crncevic-Orlic Z, Kovac Z, Polasek O, Soldo-Juresa D. Vitamin D status, dependence on age, and seasonal variations in the concentration of vitamin $D$ in Croatian postmenopausal women initially screened for osteoporosis. Clin Rheumatol 2010;29:861-867.

17. Amiri $P$, Asghari $G$, Sadrosadat $H$, Karimi $M$, Amouzegar A, Mirmiran P et al. Psychometric Properties of a Developed Questionnaire to Assess Knowledge, Attitude and Practice Regarding Vitamin D (D-KAP-38). Nutrients 2017;9:471.
18. Shivappa N, Steck SE, Hurley TG, Hussey JR, Hébert JR. Designing and developing a literature-derived, population-based dietary inflammatory index. Public Health Nutr 2014;17:1689-1696.

19. Vranešić Bender D, Giljević Z, Kušec V, Laktašic Žerjavić $N$, Bošnjak Pašic $M$, Vrdoljak $E$ et al. Guidelines for the Prevention, Detection and Therapy of Vitamin D Deficiency in Adults. Lijec Vjesn 2016;138:121-132.

20. Rudnicka A, Adoamnei E, Noguera-Velasco JA, Vioque J, Cañizares-Hernández F, Mendiola J et al. Vitamin D status is not associated with reproductive parameters in young Spanish men. Andrology 2019;10.

21. Correa-Rodríguez M, Pocovi G, Schmidt-RioValle J, González-Jiménez E, Rueda-Medina B. Assessment of dietary intake in Spanish university students of health sciences. Endocrinol Diabetes Nutr 2018;65:265-273.

22. Fredriksson E, Brekke HK, Ellegård L. Dietary intake in Swedish medical students during 2007-2012. Scand J Public Health 2016;44:77-83.

23. Frida Food Data [Internet]. Kongens Lyngby: National Food Institute, Technical University of Denmark, c2015 [cited 2020 Jan 22]. Available from: http://frida.fooddata.dk.

24. World Health Organization [Internet]. Copenhagen: WHO Regional Office for Food-based dietary guidelines in the WHO European Region, Inc. c2003. [cited 2020 Jan 22]. Available from: https://www.euro.who.int/_ data/assets/pdf_file/0017/150083/E79832.pdf.

25. Jovanović GK, Kresić G, Zezelj SP, Mićović V, Nadarević VS. Cancer and cardiovascular diseases nutrition knowledge and dietary intake of medical students. Coll Antropol 2011;35:765-774.

26. Kresić G, Kendel Jovanović G, Pavicić Zezel S, Cvijanović $\mathrm{O}$, Ivezić $\mathrm{G}$. The effect of nutrition knowledge on dietary intake among Croatian university students. Coll Antropol 2009;33:1047-1056.

27. de Oliveira Otto MC, Mozaffarian D, Kromhout D, Bertoni AG, Sibley CT, Jacobs Jr DR et al. Dietary intake of saturated fat by food source and incident cardiovascular disease: the Multi-Ethnic Study of Atherosclerosis. Am J Clin Nutr 2012;96:397-404.

28. Wu JHY, Micha R, Mozaffarian D. Dietary fats and cardiometabolic disease: mechanisms and effects on risk factors and outcomes. Nat Rev Cardiol 2019;16:581-601.

29. Labuschagne IL, Blaauw R. An anti-inflammatory approach to the dietary management of multiple sclerosis: a condensed review. South Afr J Clin Nutr 2018;31: 67-73.

30. Liu W, Zhang L, Xu HJ, Li Y, Hu CM, Yang JY, et al. The Anti-Inflammatory Effects of Vitamin $D$ in Tumorigenesis. Int J Mol Sci 2018;19:2736.

31. Kenđel Jovanović $G$, Pavičić Žeželj S, Klobučar Majanović $S$, Mrakovcic-Sutic I, Šutić I. Metabolic syndrome and its association with the Dietary Inflammatory Index (DII) ${ }^{\circledR}$ in a Croatian working population. J Hum Nutr Diet 2020; 33:128-137.

32. Hébert JR, Shivappa N, Wirth MD, Hussey JR, Hurley TG. Perspective: The Dietary Inflammatory Index (DII)-Lessons Learned, Improvements Made, and Future Directions. Adv Nutr 2019;10:185-195.

33. Carvalho CA, Silva AAM, Assunção MCF, Fonseca PCA, Barbieri MA, Bettiol $\mathrm{H}$, et al. The dietary inflammatory index and insulin resistance or metabolic syndrome in young adults. Nutrition 2019;58:187-193. 
34. Açik $M$, Çakiroğlu FP. Evaluating the Relationship between Inflammatory Load of a Diet and Depression in Young Adults. Ecol Food Nutr 2019;58:366-378.

35. Correa-Rodríguez M, Rueda-Medina B, González-Jiménez E, Correa-Bautista JE, Ramírez-Vélez R, Schmidt-RioValle J. Dietary inflammatory index, bone health and body composition in a population of young adults: a cross-sectional study. Int J Food Sci Nutr 2018;69:10131019.

36. Žeželj SP, Tomljanović A, Jovanović GK, Krešić G, Cvijanović Peloza O, Dragaš-Zubalj N, et al. Prevalence, Knowledge and Attitudes Concerning Dietary Supplements among a Student Population in Croatia. Int J Environ Res Public Health 2018;15:1058.

37. O'Connor C, Glatt D, White L, Revuelta Iniesta R. Knowledge, Attitudes and Perceptions towards Vitamin $D$ in a UK Adult Population: A Cross-Sectional Study. Int J Environ Res Public Health 2018;15:2387.

38. Zhou M, Zhuang W, Yuan Y, Li Z, Cai Y. Investigation on vitamin $D$ knowledge, attitude and practice of university students in Nanjing, China. Public Health Nutr 2016;19: 78-82.

39. Jablonski NG, Chaplin $G$. The roles of vitamin $D$ and cutaneous vitamin $D$ production in human evolution and health. Int J Paleopathol 2018;23:54-59.

40. Kimlin MG. Geographic location and vitamin D synthesis. Mol Aspects Med. 2008;29(6):453-461.
41. Kung AW, Lee KK. Knowledge of vitamin D and perceptions and attitudes toward sunlight among Chinese middle-aged and elderly women: a population survey in Hong Kong. BMC Public Health 2006;6:226.

42. Ho-Pham L, Nguyen M. Survey on Knowledge and Attitudes on Vitamin D and Sunlight Exposure in an Urban Population in Vietnam. J ASEAN Fed Endocr Soc 2014; 27:191.

43. Holick MF. The vitamin D deficiency pandemic: Approaches for diagnosis, treatment and prevention. Rev Endocr Metab Disord 2017;18:153-165.

44. Ermertcan AT, Oztürkcan S, Dinç G, Yurtman D, Pala T, Sahin MT. Sunscreen use and sun protection practices in students and personnel of Celal Bayar University. Photodermatol Photoimmunol Photomed 2005;21:191-197.

45. Almuqati RR, Alamri AS, Almuqati NR. Knowledge, attitude, and practices toward sun exposure and use of sun protection among non-medical, female, university students in Saudi Arabia: A cross-sectional study. Int J Womens Dermatol 2019;5:105-109.

46. AlGhamdi KM, AlAklabi AS, AlQahtani AZ. Knowledge, attitudes and practices of the general public toward sun exposure and protection: A national survey in Saudi Arabia. Saudi Pharm J 2016;24:652-657.

47. Al Robaee AA. Awareness to sun exposure and use of sunscreen by the general population. Bosn J Basic Med Sci 2010;10:314-318. 